\title{
Gall stones in Jamaican children with homozygous sickle cell disease
}

\author{
D K H WEBB, ${ }^{*}$ J S DARBY, $\dagger$ D T DUNN, ${ }^{*}$ S I TERRY, $\ddagger$ AND G R SERJEANT* \\ ${ }^{*}$ Medical Research Council Laboratories (Jamaica) and the Departments of $¥$ Medicine and $†$ Radiology, \\ University of the West Indies, Kingston, Jamaica
}

SUMMARY Gall stones were detected by ultrasonography in 30 of $226(13 \%)$ children with homozygous sickle cell disease aged 5-13 years participating in a cohort study from birth. Children with gall stones had significantly lower total haemoglobin and fetal haemoglobin and higher bilirubin concentrations, but further analysis showed that the apparent effects of haemoglobin and fetal haemoglobin concentration were secondary to their relationship with bilirubin concentrations. Abdominal pain crises were significantly associated with gall stones but both factors appeared to reflect an increased clinical severity and were probably not causally related. No patients had symptoms specific of gall stones and an association with abdominal pain crisis should not, of itself, be considered an indication for surgery.

Pigment gall stones are well recognised as a complication of sickle cell disease but previous data on their prevalence and pathologic significance have been collected from symptomatically ascertained patient populations. The present study reports the prevalence in a representative sample of patients with homozygous sickle cell disease followed up in a cohort study from birth. This has also allowed an assessment of risk factors for gall stone formation and an analysis of associated symptomatology.

\section{Subjects and methods}

The children participated in a cohort study of sickle cell disease, which has been previously described. ${ }^{12}$ During the screening of $100000^{\circ}$ consecutive deliveries, 314 children with homozygous sickle cell disease were detected of whom six were lost to follow up immediately; 308 were admitted to the cohort study and followed up prospectively. Of these, 53 died, nine emigrated, and 246 (aged 5-13 years) continued to be observed at the time of the study.

From January to May 1987 all available children were examined by an experienced radiologist (JSD) using an ATL Ultramark IV with $3.0 \mathrm{mHz}$ sector transducer. All studies were conducted in both transverse and longitudinal planes, with patients in a fasting state. Gall stones were diagnosed on the basis of echodense images within the gall bladder with either acoustic shadowing or gravitational change in position.
The haematological risk factors for gall stone formation were examined by comparing the means of steady state haematological indices in children with and without gall stones by Student's $t$ test and by logistic regression analysis. These analyses were confined to steady state values over the age of 4 years because of rapid age related changes before this age. ${ }^{2}$ All variables except total haemoglobin and direct bilirubin were transformed $\left(\log _{10}\right.$ $($ variable+1)) to produce approximately normal distributions before analysis. These observations were also used to predict gall stone frequency according to age and total bilirubin concentration.

Clinical features were also compared in patients with and without gall stones. Pain crises were defined as pain severe enough to limit activity and to require narcotic analgesia and were divided into those affecting primarily the bones or joints (bone pain crisis) or the abdomen (abdominal pain crisis). Dactylitis was defined as painful, tender swelling over the small bones of the hand, foot, or digits with no evidence of local infection. Acute chest syndrome was characterised by fever, tachypnoea, and signs of pulmonary consolidation. Septicaemia referred to a clinically ill child with fever, positive blood culture, and no other focus of infection. The growth of children with and without gall stones was assessed by comparing mean heights and weights at the 5th and 9 th birthdays.

The frequency of clinical events was assessed by deriving age specific incidence rates for pain crises, acute chest syndrome, and dactylitis in children with 
and without gall stones. As a few children with multiple events may distort these rates, a scoring system of 1-5 was used for bone pain crises and acute chest syndrome (representing $0,1,2-4,5-9$, 10 or more events) and of 1-4 for abdominal pain crises (representing $0,1,2,3$ or more events). These age specific incidence rates, derived for one year age bands, were compared between groups by analysis of variance. The relation of abdominal pain crisis with gall stones was reanalysed after controlling for bone pain crisis by examining this relation in groups matched for bone crisis frequency. This approach gives similar results to the stratified test for trend suggested by Mantel. ${ }^{4}$

\section{Results}

Technically satisfactory ultrasound examinations were obtained in 226 of $246(92 \%)$ of all available patients. Gall stones occurred in 30 (19 boys, 11 girls), increased with age, and reached a prevalence of $20 \%$ in those aged $11-13$ years (table 1 ). Among those affected, the male:female ratio was $2 \cdot 5: 1$ in the 5-7 year age group and 1.3:1 in children aged 11-13, but the overall sex difference was not significant $\left(\chi_{1}^{2}=0.62, \mathrm{p}=0.42\right)$.

Comparison of haematological indices showed that children with gall stones had significantly lower total haemoglobin and fetal haemoglobin and higher

Table 1 Prevalence of gall stones according to age and sex

\begin{tabular}{|c|c|c|c|c|c|c|}
\hline \multirow{2}{*}{$\begin{array}{l}\text { Age } \\
\text { group } \\
\text { (years) }\end{array}$} & \multicolumn{2}{|c|}{ Boys } & \multicolumn{2}{|c|}{ Girls } & \multicolumn{2}{|c|}{ Total } \\
\hline & No & $\begin{array}{l}\text { No (\%) } \\
\text { gall } \\
\text { stones }\end{array}$ & No & $\begin{array}{l}\text { No (\%) } \\
\text { gall } \\
\text { stones }\end{array}$ & No & $\begin{array}{l}\text { No }(\%) \\
\text { gall } \\
\text { stones }\end{array}$ \\
\hline $\begin{array}{c}5-7 \\
8-10 \\
11-13\end{array}$ & $\begin{array}{l}42 \\
44 \\
35\end{array}$ & $\begin{array}{l}5(12) \\
6(14) \\
8(23)\end{array}$ & $\begin{array}{l}37 \\
32 \\
36\end{array}$ & $\begin{array}{ll}2 & (5) \\
3 & (9) \\
6 & (17)\end{array}$ & $\begin{array}{l}79 \\
76 \\
71\end{array}$ & $\begin{array}{r}7(9) \\
9(12) \\
14(20)\end{array}$ \\
\hline Total & 121 & $19(16)$ & 105 & $11(11)$ & 226 & $30(13)$ \\
\hline
\end{tabular}

bilirubin concentrations (table 2). As these results may be influenced by mutual correlations between indices and the effects of age and sex, logistic regression analysis was used to assess the effect of each independently. Fitting all variables to two different models utilising either total bilirubin (model 1) or direct and indirect bilirubin (model 2), only total bilirubin $(p=0.02)$ and indirect bilirubin $(p=0.04)$ were significant indicating that after allowance for these factors, there was no additional effect of either haemoglobin or fetal haemoglobin. Results from the second model are shown in table 3. The predicted frequency of gall stones derived for different ages and bilirubin concentrations is shown in fig 1 .

The scores for bone and abdominal pain crises (figs 2 and 3), and for acute chest syndrome, were consistently higher in children with gall stones, although only the difference for abdominal pain crisis reached significance $\left(F_{1,28}=4 \cdot 02, p=0.05\right)$. This observation could either imply a causal association between gall stones and abdominal pain crisis or that both factors reflect increased clinical severity. Analysis, repeated after controlling for bone pain crisis, showed that the relation of gall stones and abdominal pain crisis was no longer significant implying that their coincidence most likely reflected

Table 3 Logistic regression analysis of some haematological and clinical features in patients with gall stones

\begin{tabular}{lcl}
\hline Variable & $\begin{array}{l}\text { Slope* } \\
\text { (logistic scale) }\end{array}$ & Significance \\
\hline Age & 0.09 & 0.32 \\
Sex (female) & -0.19 & 0.67 \\
Haemoglobin & -0.32 & 0.25 \\
Fetal haemoglobin $\dagger$ & -0.34 & 0.37 \\
Reticulocytes $\dagger$ & 0.05 & 0.96 \\
Direct bilirubin & 0.06 & 0.27 \\
Indirect bilirubin $\dagger$ & 0.79 & 0.04 \\
\hline
\end{tabular}

*After allowance for all other variables.

$\dagger$ Transformed variables.

Table 2 Haematology investigations in children with and without gall stones

\begin{tabular}{|c|c|c|c|c|c|c|}
\hline \multirow[t]{2}{*}{ Variable } & \multicolumn{2}{|c|}{ Gall stones present $(n=30)$} & \multicolumn{2}{|c|}{ Gall stones absent $(n=196)$} & \multirow[t]{2}{*}{$t$} & \multirow[t]{2}{*}{ p Value } \\
\hline & Mean & $S D$ & Mean & $S D$ & & \\
\hline $\begin{array}{l}\text { Fetal haemoglobin* } \\
\text { Haemoglobin }(\mathrm{g} / \mathrm{l}) \\
\text { Reticulocytes* } \\
\text { Direct bilirubin }(\mu \mathrm{mol} / \mathrm{l}) \\
\text { Indirect bilirubin* } \\
\text { Total bilirubin* }\end{array}$ & $\begin{array}{l}0.72(4 \cdot 3) \\
74 \\
1.09(11) \\
17 \\
1.42(25) \\
1.64(43)\end{array}$ & $\begin{array}{l}0 \cdot 23 \\
8 \cdot 5 \\
0 \cdot 09 \\
3 \cdot 4 \\
0 \cdot 24 \\
0 \cdot 17\end{array}$ & $\begin{array}{l}0.84(5.9) \\
79 \\
1.06(10) \\
15 \\
1.26(17) \\
1.53(33)\end{array}$ & $\begin{array}{l}0 \cdot 28 \\
9 \cdot 6 \\
0 \cdot 11 \\
4 \cdot 0 \\
0 \cdot 25 \\
0 \cdot 17\end{array}$ & $\begin{array}{r}2 \cdot 15 \\
2 \cdot 64 \\
-1 \cdot 30 \\
-2 \cdot 16 \\
-3 \cdot 19 \\
-3 \cdot 46\end{array}$ & $\begin{array}{l}0 \cdot 03 \\
0 \cdot 009 \\
0 \cdot 19 \\
0 \cdot 03 \\
0 \cdot 002 \\
0 \cdot 001\end{array}$ \\
\hline
\end{tabular}

*Indices expressed as values transformed by $\log _{10}($ variable +1$)$.

Figures in parentheses indicate means re-expressed in original units. 


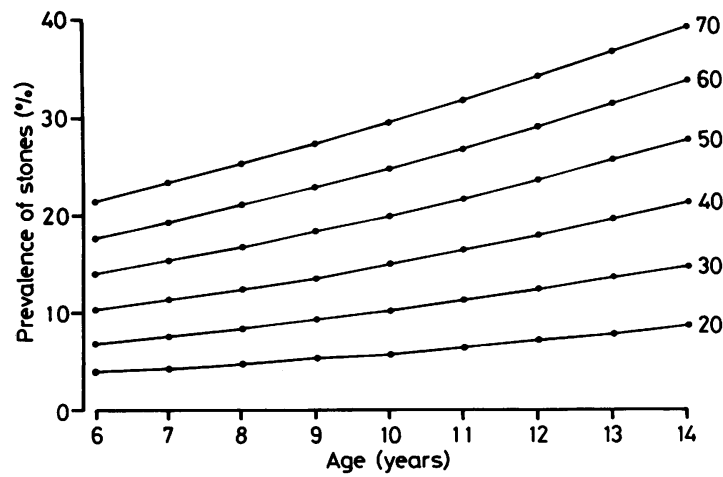

Fig 1 Expected frequency of gall stones at different ages for different total bilirubin concentrations ( $\mu$ molll) derived from the observations.

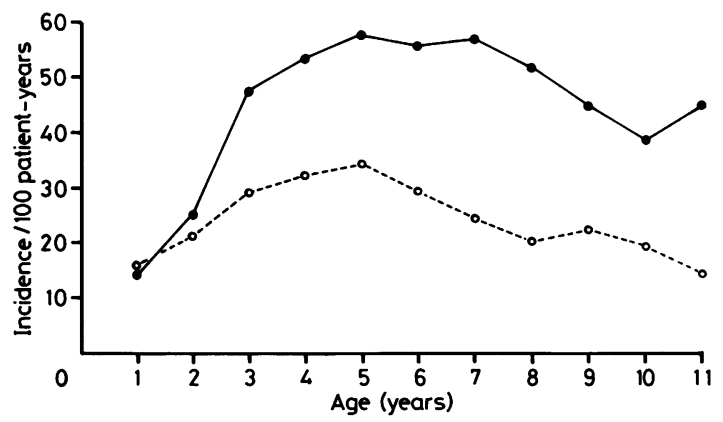

Fig 2 Incidence of bone pain crises (derived as scores) in children with (O) and without $(\mathrm{O}---\mathrm{O})$ gall stones.

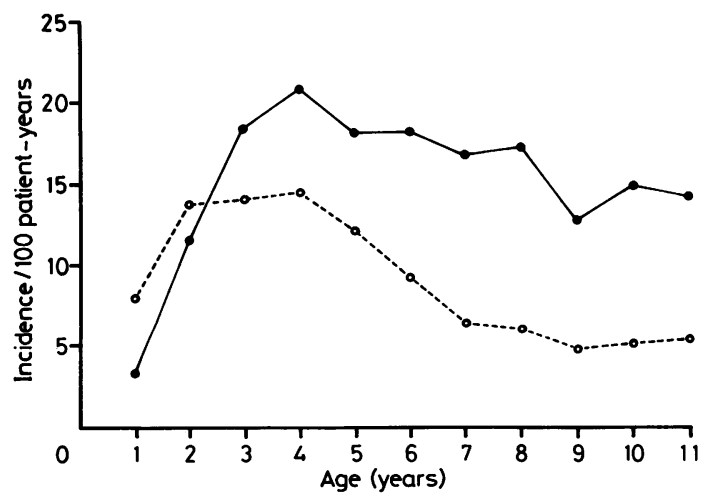

Fig 3 Incidence of abdominal pain crises (derived as scores) in children with (-) and without $(\mathrm{O}--\mathrm{O})$ gall stones. an increased disease severity. No child had specific symptoms attributable to gall stones, and pain in the abdominal painful crisis was not localised to the right upper quadrant or epigastrium.

There were no differences in the incidence of septicaemia or dactylitis or in growth between the groups.

\section{Discussion}

The prevalence of gall stones in this representative group of Jamaican children with homozygous sickle cell disease was $13 \%$, considerably lower than the figures of $28-33 \%$ reported in age comparable groups in the United States. ${ }^{5-8}$ In view of the genetic similarity of the two populations, it is likely that this difference represents the greater symptomatic selection in American series.

Information from other geographic areas is difficult to interpret. In Nigeria a low prevalence of cholelithiasis of $6 \%$ in patients under 15 years in one study ${ }^{9}$ might have been attributed to the less sensitive diagnostic method of oral cholecystography, but later studies using ultrasonography reported similar low prevalences of $4.4 \%$ under 17 years ${ }^{10}$ and $5 \%$ under 15 years. ${ }^{11}$ It therefore seems likely that gall stones are truly infrequent in young Nigerian patients with homozygous sickle cell disease consistent with the infrequency of all gall stones in that population. ${ }^{12}$ Since bilirubin concentrations in Nigerian patients with homozygous sickle cell disease are similar to those in Jamaica it must be concluded that pigment cholelithiasis is also influenced by other, possibly environmental, factors. In a Saudi Arabian study using oral cholecystography, ${ }^{13}$ cholelithiasis was observed in only $8 \%$ of a population aged 10-64 years and did not occur in 26 patients under 17 years; this is consistent with the low bilirubin and mild haematological change characterising that population.

Apparent risk factors for gall stone formation in homozygous sickle cell disease in other studies have included low fetal haemoglobin concentration and high reticulocyte count ${ }^{14}$ and high total $^{6}{ }^{14}$ and indirect ${ }^{14}$ bilirubin concentration. In the present study gall stones were associated with low total haemoglobin, low fetal haemoglobin, and high bilirubin concentrations. As both haemoglobin and fetal haemoglobin concentrations are inversely related to total bilirubin and as their contribution was lost on regression analysis it seems likely that their apparent effect was secondary to that of bilirubin concentrations.

The clinical significance of gall stones in homozygous sickle cell disease remains unclear. There is no doubt that complications such as acute cholecystitis 
or obstruction of the cystic or common bile duct may occur and may require surgical correction. The major question is the frequency of these complications and whether prophylactic cholecystectomy is justified. Gall stones affected $20 \%$ of a representative sample of Jamaican children with homozygous sickle cell disease aged 11-13 years, none of whom had symptoms clearly attributable to gall stones, although the significant association of gall stones with abdominal pain crisis might be inappropriately interpreted as an indication for cholecystectomy. Further analysis showed that such children were also more prone to bone pain crisis, and the disappearance of an association with abdominal pain crisis after correcting for bone pain frequency makes it likely that both gall stones and abdominal pain crises reflect clinical severity and are not causally related. Abdominal pain crisis in children with gall stones, therefore, should not be considered an indication for surgery unless there are features clearly referable to the right upper quadrant of the abdomen.

The arguments for prophylactic cholecystectomy of asymptomatic gall stones are based upon the assumption that these stones will become symptomatic. ${ }^{515-20}$ This assumption was strengthened by a recent report from the United Kingdom indicating that pain typical of biliary colic occurred in $68 \%$ of adults with gall stones and that $21 \%$ developed acute cholecystitis. ${ }^{20}$ It is difficult to reconcile these data with the Jamaican observations in which gall stones, although common, are relatively infrequently associated with typical symptoms. No symptoms have occurred in 30 cohort study children with gall stones - the oldest of whom are now approaching 15 years-and follow up of 32 adults known to have gall stones for 15 years showed only one patient developing specific symptoms during this period (DKH Webb and GR Serjeant, unpublished observations) and a current study of 31 patients with homozygous sickle cell disease over the age of 40 years has shown gall stones in $17(55 \%)$ yet only two $(6 \%)$ have had cholecystectomy for symptoms. A possible contributing factor to the apparent difference between the populations of the United Kingdom and Jamaica could be a greater symptomatic selection occurring in the group from the United Kingdom, and this is supported by the observation that 18 of $70(26 \%)$ patients aged 16 years and above had already had cholecystectomies before the study in the United Kingdom.

The role of cholecystectomy for symptomatic gall stones is unquestioned but the Jamaican data do not support a policy of prophylactic cholecystectomy.

\section{References}

1 Serjeant BE, Forbes M, Williams LL, Serjeant GR. Screening cord bloods for detection of sickle cell disease in Jamaica. Clin Chem 1974;20:666-9.

2 Serjeant GR, Grandison Y, Lowrie Y, et al. The development of haematological changes in homozygous sickle cell disease: a cohort study from birth to 6 years. Br J Haematol 1981;48: 533-43.

${ }^{3}$ Serjeant GR, Serjeant BE, Forbes M, Hayes RJ, Higgs DR, Lehmann $H$. Haemoglobin gene frequencies in the Jamaican population: a study in 100,000 newborns. $\mathrm{Br} J$ Haematol 1986;64:253-62.

Mantel N. Chi-square tests with one degree of freedom; extensions of the Mantel-Haenszel procedure. Journal of American Statistical Association 1963;58:690-700.

5 Lachman BS, Lazerson J, Starshak RJ, Vaughters FM, Werlin SL. The prevalence of cholelithiasis in sickle cell disease as diagnosed by ultrasound and cholecystography. Pediatrics 1979;64: 601-3.

${ }^{6}$ Sarnaik S, Slovis TL, Corbett DP, Emami A, Whitten CF. Incidence of cholelithiasis in sickle cell anemia using the ultrasonic gray-scale technique. J Pediatr 1980;96:1005-8.

${ }^{7}$ Cunningham JJ. Houlihan SM, Altay C. Cholecystosonography in children with sickle cell disease: technical approach and clinical results. J Clin Ultrasound 1981;9:231-5.

8 Rennals MB, Dunne MG, Grossman NJ, Schwartz AD. Cholelithiasis in patients with major sickle hemoglobinopathies. Am J Dis Child 1984;138:66-7.

9 Akinyanju O, Ladapo F. Cholelithiasis and biliary tract disease in sickle-cell disease in Nigerians. Postgrad Med J 1979;55:400-2.

10 Adekile AD, Makanjuola D. Ultrasonography in children with sickle cell anaemia. Journal of Nigerian Paediatrics 1983;10:35-8.

11 Akamaguna AI, Odita JC, Ugbodaga CI, Okafor LA. Cholelithiasis in sickle cell disease: a cholecystographic and ultrasonographic evaluation in Nigerians. Eur J Radiol 1985;5:271-2.

12 Da Rocha-Afodu JT, Adesola AO. Cholecystitis in Nigerians. Journal of the Nigerian Medical Association 1971;1:47-50.

${ }^{13}$ Perrine RP. Cholelithiasis in sickle cell anemia in a Caucasian population. Am J Med 1973;54:327-32.

14 McCall IW, Desai P, Serjeant BE, Serjeant GR. Cholelithiasis in Jamaican patients with homozygous sickle cell disease. Am J Hematol 1977;3:15-21.

15 Karayalcin G, Hassani N, Abrams M, Lanzkowsky P. Cholelithiasis in children with sickle cell disease. Am J Dis Child 1979;133:306-7.

16 Spigelman A, Warden MJ. Surgery in patients with sickle cell disease. Arch Surg 1972;104:761-4.

17 Ariyan S, Shessel FS, Pickett LK. Cholecystitis and cholelithiasis masking as abdominal crises in sickle cell disease. Pediatrics 1976;58:252-8.

18 Solanki DL, McCurdy PR. Cholelithiasis in sickle cell anemia: a case for elective cholecystectomy. Am J Med Sci 1979;277: 319-24.

19 Stephens CG, Scott RB. Cholelithiasis in sickle cell anemia: surgical or medical management. Arch Intern Med 1980;140: 648-51.

20 Bond LR, Hatty SR, Horn MEC, Dick M, Meire HB, Bellingham AJ. Gallstones in sickle cell disease in the United Kingdom. Br Med J 1987;295:234-6.

Correspondence and requests for reprints to Professor GR Serjeant, Medical Research Council Laboratories, University of the West Indies, Kingston 7, Jamaica.

Accepted 1 November 1988 